\title{
Kvalita života v době koronaviru z perspektivy sociální práce Karel Řezáč
}

DOI: $10.32725 /$ cetv.2021.010

\begin{abstract}
Abstrakt:
Doba koronavirové krize zasáhla prakticky každý aspekt našeho života. Přesto jsou ve veřejném prostoru diskutovány dopady pandemie a s ní souvisejících opatření nejčastěji v kontextu zdravotních a ekonomických aspektů sociálního života. Sociální práce ze své komplexní podstaty umožňuje nahlížet na problémy $v$ širších souvislostech, a proto se její perspektiva jeví jako vhodná pro upozornění na všestranné následky pandemie a jejich dopad na kvalitu života. Cílem této teoretické studie je diskutovat a upozornit na rizika týkající se kvality života, která vyplývají z epidemie onemocnění covid-19 a s ní souvisejících opatření perspektivou sociální práce. Pro zohlednění širší perspektivy náhledu na kvalitu života bylo pro analýzu současného stavu využito koncepce capability approach a z ní vyplývajících základních lidských potencialit.
\end{abstract}

Klíčová slova: koronavirus, sociální práce, kvalita života, zdraví, capability approach, potenciality, covid-19

\section{Úvod}

Všudypřítomnost koronavirové krize pohltila rok 2020 prakticky od jeho samotného počátku. Již koncem ledna tohoto roku zaznamenalo téma koronaviru v kontextu České republiky 99 \% populace. ${ }^{1}$ Slovo koronavirus se v daném roce stalo nejvyhledávanějším slovem globálně nejpoužívanějšího internetového vyhledávače. ${ }^{2}$ Koronavirová krize nabyla takových rozměrů, že její ekonomické dopady byly přirovnávány $\mathrm{k}$ důsledkům druhé světové války a rozsah jejího vlivu zasáhl nejen globální zdravotnické systémy, ale prakticky každý aspekt lidského života. ${ }^{3}$ Reakcí na tento stav bylo zavedení restriktivních opatření, která pandemii neodmyslitelně provázejí. Tato opatření, v nejstriktnější podobě označovaná jako lockdown, se ukazovala jako klíč k zamezení šíření

1 () MEDIAN, s.r.o., Koronavirus. Tisková zpráva (on-line), dostupné na: https://www.median.eu/cs/wp-content/uploads/2020/01/ MEDIAN_Tiskova_zprava_Koronavirus_20200131.pdf, citováno dne 29.12. 2020.

2 (C) Google, Rok 2020 ve vyhledávání (on-line), dostupné na: https://trends.google.com/trends/yis/2020/GLOBAL/, citováno dne 29. 12. 2020.

3 Maria NICOLA, a kol., The socio-economic implications of the coronavirus pandemic (COVID-19): A review, International Journal of Surgery 78/2020, s. 185. 
epidemie, přičemž jeho včasné využití v Polsku a České republice v polovině dubna sloužilo jako ilustrativní př́iklad dobré praxe zpomalení šíření epidemie. ${ }^{4}$ Bohužel naše trpělivost při ponechání „Zavřených dveří nebyla dostatečná, aby nás před krizí ochránila, pouze zpomalila nástup její gradace. Ochrana zdraví (snad právem) v této době získala legitimní monopol na intervenci do všech oblastí lidského života. „Zdraví nadevše“, tak by se dala charakterizovat filosofie doby koronaviru. Je však tato rétorika a optika skutečně univerzálně platná a nebude nakonec zvládnutí pandemie prostřednictvím tvrdých restrikcí Pyrrhovo vítězství medicíny se značnými ztrátami v ostatních aspektech kvality života? Odpověd’ na tuto otázku dost možná nepřinese ani čas, jelikož půjde jen velmi obtížně a nepřesně určit, do jaké míry ovlivnila protiepidemická opatření kvalitu života nás všech a jak moc byla tato opatření nevyhnutelná $\mathrm{z}$ hlediska zajištění rychlého návratu ke standardní podobě života. Tento (někdy až frustrující) paradox je dobře znám všem, kteří pracují $\mathrm{v}$ oblasti sociální práce a v pomáhajících profesích. Efekt intervence pracovníka často nelze změřit, a její význam pro dosažení změny tak nelze prokazatelně interpretovat. Vedle toho jsme v kontextu tradiční sociálně ekologické perspektivy sociální práce zvyklí pracovat s komplexním všestranným náhledem na klienta a jeho obtižze. ${ }^{5}$ z tohoto důvodu se sociální práce jeví jako relevantní oblast, které náleží nárok upozornit na možné potenciální dopady protiepidemických opatření v kontextu komplexního pohledu na kvalitu života. Cílem této teoretické studie tedy je diskutovat a upozornit na rizika týkající se kvality života, která vyplývají z epidemie onemocnění covid-19 a s ní souvisejících opatření, a sice právě perspektivou sociální práce.

\section{Metodika}

Za účelem naplnění cíle této teoretické studie byla zvolena metoda přehledové studie. $V$ zásadě existují dva druhy přehledových studií. První, běžnější druh bývá součástí originální výzkumné studie, tedy studie, která referuje o jednom výzkumu. Druhý, specifiččejší druh má podobu samostatné, ucelené přehledové studie, která mapuje výzkum ve zvolené oblasti. V odborné literatuře se však můžeme setkat s řadou odlišných typů přehledových studií. Jejich označení, obsahové zaměření i uváděné počty jsou u jednotlivých autorů rozdílné. ${ }^{6}$ Jedním z typů přehledových studií je tzv. rapid review, tedy rychlý přehled. Jedná se o studii, která má rámcově reagovat na jeden problém v relativně omezeném čase. Autor na základě zadání definuje kritéria rešerše zdrojů klíčových nebo aktuálních publikací, popiše a utřídí prezentovaná data studií a na jejich základě formuluje své závěry. ${ }^{7}$ Ačkoliv je v př́padě této metody limitem zobecnění závěrů a interpretace nálezů je vázána na zdroje dohledané $\mathrm{v}$ omezeném čase, výhodou je možnost reflektování aktuálního tématu v bezprostředním a relevantním čase. Právě tato výhoda byla klíčová pro volbu tohoto typu přehledové studie, nebơ „doba koronaviru“, která utváří stěžejní kontext textu, je záležitostí aktuální a trvající od minulého roku. Přestože již zahrnuje řadu relevantních studií, není oblastí natolik rozsáhlou, aby umožnila standardní systematické studování vyžadující v průměru dva roky bádání. ${ }^{8}$ Této skutečnosti byla podřízena také kritéria rešerše, respektive volby textů přehledové studie. $V$ první řadě byly vyhledávány standardní výzkumy publikované v odborných recenzovaných časopisech. $Z$ důvodu předpokladu omezenějšího výběru však byly

4 Shuliang O. CHENG, Shehryar KHAN, Europe's response to COVID-19 in March and April 2020 - A letter to the editor on "World Health Organization declares global emergency: A review of the 2019 novel coronavirus (COVID-19)", International Journal of Surgery 78/2020, s. 3.

5 Roman BALÁŽ, Komplexní posouzení: Spojení studia sociálních deviací se sociální prací, Sociální práce / Sociálna práca 6/2018, s. 28.

6 Jiří MAREŠ, Přehledové studie: jejich typologie, funkce a způsob vytváření, Pedagogická orientace 4/2013, s. 429.

7 Tamtéž, s. 431.

8 Tamtéž. 
akceptovány také výzkumné zprávy př́śsušných institucí, oficiální dokumenty a ojediněle i jiné z hlediska původu relevantní zdroje. Vždy bylo přitom dbáno na dodržení kritérií relevance textu dle metody RADAR, která byla publikována v roce 2013 primárně pro orientaci studentů ve světě elektronických zdrojů, ale její univerzálnost umožňuje a předpokládá využití napříč prakticky všemi úrovněmi studia textu. ${ }^{9}$ Texty pro studii byly vyhledávány prostřednictvím on-line databází vědeckých studií a internetovými vyhledávači na základě hesel kombinujících označení covid-19 apod. a prŕslušných potencialit, respektive oblastí kvality života. Pro účely studie byly zvoleny ty texty, které nejrelevantněji reprezentovaly poznatky o dopadech pandemie v dané oblasti.

\section{Perspektiva sociální práce}

Obecné definice sociální práce představují interpretaci společných témat sociální práce, kterými jsou jednotlivec - interakce - prostředí. ${ }^{10}$ Klíčem k porozumění specifické optice sociální práce je pojem, který zajištuje dynamiku mezi uvedenými tématy, respektive subjekty sociální práce, tedy sociální fungování. ${ }^{11}$ Užívání termínu sociálního fungování přesahuje hranice určité teoretické školy či specifického modelu sociální práce. Podpora sociálního fungování začala být totiž vnímána také jako jeden $\mathrm{z}$ hlavních cílů sociální práce coby specifické profese. ${ }^{12}$ Pojem označuje schopnost člověka zvládat očekávání prostředí, jehož je součástí. Mezi jednotlivci a prostředím dochází $\mathrm{k}$ neustálé interakci, která je za běžných okolností v rovnováze. Pokud lidé požadavky prostř̌edí dostatečně nezvládají, rovnováha je rozkolísána a vzniká sociální problém, jenž je předmětem sociální práce. ${ }^{13}$ Toto funkcionalistické pojetí, respektive podstata a legitimita očekávání prostředí je někdy v kontextu pozdně moderní společnosti vystaveno snahám o jeho více individualizovanou reformulaci například do podoby reflexivního zvládání problémi ${ }^{14}$ nebo do rozšiřrené perspektivy interakce doplněné o dimenzi očekávání jednotlivce, tedy svobodnou volbu hodnotného života mezi různými způsoby žití. ${ }^{15}$ Navzdory těmto skutečnostem je $\mathrm{v}$ textu vycházeno z původního funkcionalistického pojetí, jelikož ona zmíněná potřeba individualizace je součástí interpretace pojmu kvalita života $\mathrm{v}$ př́slušné části textu.

Významnou součástí koncepce funkcionalistického pojetí sociální práce je také pojem životní situace. Podpora rovnováhy mezi klientem a jeho sociálním prostředím je podmíněna zaměřením na komplex různorodých okolností, které ve svém souhrnu představují specifickou životní situaci klienta. Mezi tyto okolnosti patř́ jak charakteristiky jedinců nebo skupin, tak charakteristiky prostředí, ve kterém tito jedinci a skupiny žiji. ${ }^{16}$ Sociální pracovník se zaměřuje na dílčí dimenze situace klienta. $\mathrm{V}$ závislosti na tomto zaměření se liší př́stup sociálních pracovníků. Předmětem jejich intervence by měla být situace klienta jako celek. Sociální pracovník by měl rozpoznat všechny (zdravotní, psychiatrické, psychologické, ekonomické, kvalifikační, duchovní, hodnotové a kulturní, hygienické, vztahové a případné další) bariéry působící v procesu zvládání situace

9 Jane MANDALIOS, RADAR: An approach for helping students evaluate Internet sources, Journal of Information Science 4/2013, s. $470-478$.

10 Srov. Libor MUSIL, Daniela JAKLOVÁ STŘIHAVKOVÁ, Reflecting on a Common Core and the Variability of Social Work Definitions: "Theme and its Interpretations" by Foucault, Journal of Social Work Education 2/2020, s. 384-393.

11 Srov. Pavel NAVRÁTIL, Libor MUSIL, Sociální práce s př́slušníky menšinových skupin, in: Sborník prací fakulty sociálních studií brněnské univerzity, Sociální studia č. 5, Brno: Fakulta sociálních studií, 2000, s. 118.

12 Pavel NAVRÁTIL, Reflexivní posouzení v sociální práci s rodinami, Brno: MUNI PRESS, 2014, s. 50.

13 Srov. NAVRÁTIL, MUSIL, Sociální..., s. 118.

14 Srov. NAVRÁTIL, Reflexivní..., s. 77.

15 Srov. Karel ŘEZÁČ, Koncepce očekávání jako komplexní evaluační nástroj v sociálních vědách, Sociální práce / Sociálna práca 6/2020, s. 23-34.

16 Libor MUSIL, „Ráda bych Vám pomohla, ale... “Dilemata práce s klienty v organizacích, Brno: MZ, 2004, s. 15. 
klientem a promýšlet souvislosti mezi nimi. Právě toto zaměření na vzájemnou podmíněnost různorodých okolností klientova života vyvolává potřebu spolupráce pracovníků i z jiných pomáhajících profesí. Těm jejich specializace umožňuje proniknout do hloubky a složitosti dílčích dimenzí životních situací a současně jim brání věnovat pozornost jejich celku. Sociální pracovník by se měl zabývat tímto celkem. Při překonávání dílčích částí celého komplexu překážek při zvládání životní situace se však on ani jeho klient neobejde bez spolupráce s jinými specialisty. Odsud plyne, že významnou součástí organizace intervencí sociální práce je zajištění návaznosti cílů, vazeb a činností různých pomáhajících profesí. Rubem této skutečnosti je, že špatná koordinace činnosti různých pomáhajících oborů mívá pro realizaci cílů sociální práce a pro její klienty neblahé a často fatální důsledky. ${ }^{17}$ Termín životní situace označuje za prvé mnohovrstevnatost a neopakovatelnost faktorů, které brání nebo naopak usnadňují sociální fungování jednotlivého klienta nebo specifické kategorie klientů. Tento pojem také vymezuje vlastní předmět intervence sociálního pracovníka. Reflexe životní situace klienta (nebo kategorie klientů) je prvním a nezbytným krokem k volbě takových cílů a metod intervence, které mohou přispět ke změně životní situace klienta, posílit jeho schopnost zvládat požadavky prostředí a přispět tak k obnovení nebo udržení jeho sociálního fungování. ${ }^{18}$

Rozsah koronavirové krize, zejména v důsledku zmíněných opatření, dosahuje takové šíre, že si lze jen těžko představit člověka, jehož životní situaci by znatelným způsobem nezasáhla. Životní situace přitom výrazně souvisí s kvalitou života, která byla ještě v relativně nedávné době definována ve výrazně medicínském diskurzu spojeném s omezením na význam nemoci a léčby. ${ }^{19}$ Navzdory tomu, že dnes řada autorů interpretuje tento pojem z širší perspektivy, která je předestřena v nadcházející kapitole, v kontextu koronavirové krize jsou skloňovány zejména uvedené zdravotní a dále také ekonomické dopady na kvalitu života. Jak ilustruje kvantitativní výzkum agentury Behavio z dubna 2020, obavy lidí spojené s koronavirovou krizí nejčastěji zahrnovaly strach z nemoci, pokrytí životních nákladů, ztráty zaměstnání, snížení životní úrovně a zajištění splátek. ${ }^{20}$ Tento obraz bylo možné pozorovat $\mathrm{v}$ průběhu celého roku, kdy subjektivní pocit $\mathrm{z}$ prezentování dat přírůstku pozitivně testovaných lidí a nabývajících stovek miliard korun plánovaného schodku státního rozpočtu České republiky pro nadcházející rok dosáhl napříč společností v metaforické nadsázce takové sledovanosti, která bývá charakteristická spíše pro předpověd' počasí nebo významné sportovní výsledky. Je paradoxem, který je třeba si se vším respektem $\mathrm{k}$ závažnosti epidemie $\mathrm{z}$ odborného hlediska přiznat, že jen málokdo $\mathrm{z}$ nás uměl tato data správně interpretovat $\mathrm{z}$ důvodu časté absence kontrolního vzorku, tedy podobných záznamů o standardním rozsahu jiného virového onemocnění, které obvykle ani nepodléhá tak rozsáhlému testování. Vnímat dopad této krize na kvalitu života pouze měřítkem peněz a počtu nemocných by však bylo krátkozraké a iluzivní.

\section{Kvalita života}

Abychom mohli zohlednit širší perspektivu dopadů koronavirové krize, je třeba tudíž vymezit pojem kvalita života $\mathrm{v}$ přesnějším, respektive širším kontextu. Náhled na člověka jako holistickou

17 Tamtéž, s. 17.

18 Srov. NAVRÁTIL, MUSIL, Sociální..., s. 120.

19 Gary ROSENBERG, Gary HOLDEN, The Role of Social Work in Improving Quality of Life in the Community, Social Work in Health Care 25/1997, s. 13.

20 (C) Behavio Labs, s.r.o., Strach a koronavirus v Česku (on-line), dostupné na: https://behaviolabs.com/media/strach-a-koronavirus-vcesku/, citováno dne 29. 12. 2020. 
bytost zohledňující aspekty napříc biologickými, psychologickými i sociologickými funkcemi přivedlo lékařskou vědu ke komplexnímu pohledu na pacienta, což podnítilo zájem o studium kvality života nemocných. ${ }^{21}$ Koncepce kvality života představuje velmi široký komplex, jehož součástí je fyzické i psychické zdraví, vztah jedince k jeho činnostem, společnosti, prostředí, komplex životních aspektů subjektivního hodnocení vlastní životní pohody (well-beingu) a objektivních ukazatelů, jako je např́klad již zmíněná životní situace člověka. ${ }^{22}$ Pojem životní situace proto zmiňuje Světová zdravotnická organizace, která jeho prostřednictvím kvalitu života definuje. Kvalita života je touto organizací definována jako subjektivní vnímání vlastní životní situace ve vztahu ke kultuře, $\mathrm{k}$ systému hodnot, životním cílům, očekáváním, standardům a vlastním zájmům. ${ }^{23}$ Současně tato organizace formulovala podmiňující domény, které utváří komplex kvality života: (1) fyzické zdraví; (2) psychika; (3) stupeň nezávislosti; (4) sociální vztahy; (5) prostředí. ${ }^{24}$ Kvalita života je někdy také dávána do prímé souvislosti s dopady nemoci, úrazů, lékařského ošetření nebo zdravotní politiky. ${ }^{25}$ Důležité je také uvést skutečnost, že zdravotní péče má smysl do té míry, do jaké pozitivně ovlivňuje kvalitu života pacientů. ${ }^{26}$

V rámci vymezení životní pohody jsou často skloňovány dva hlavní interpretační proudy. Jedná se o objektivní a subjektivní well-being. Zatímco objektivní well-being je založen na pozorovatelných faktorech, jako je bohatství, zdraví či hmotné statky, subjektivní blahobyt znamená zejména duševní pohodu, která je člověkem prožívána z psychologického hlediska. ${ }^{27} \mathrm{~V}$ kontextu teorie capability approach lze tuto dualitu identifikovat u interpretace Sena a Nussbaumové. Zatímco Sen ve své práci staví do popředí důraz na princip svobody volby člověka a konkrétnější kategorizaci well-beingu se spíše vyhýbá, Nussbaumová, přestože ze Senova pojetí vychází, konkretizuje well-being do deseti měřitelných dimenzí. ${ }^{28}$ Aplikace tohoto prŕstupu do modelu funkcionalistické sociální práce tedy potenciálně přináší jednak výše zmíněný aspekt potřebné individualizace sociální práce a současně možnost prohloubení komplexity při hodnocení kvality života. Úkolem sociálního pracovníka $\mathrm{v}$ praxi pak je dle pojetí subjektivního well-beingu podporovat a vést klienty $\mathrm{k}$ formulaci a realizaci vlastních očekávání za účelem dosažení skutečně hodnotného života (dle vlastní determinace klienta) a konkrétní kategorizované dimenze faktorů objektivního pojetí well-beingu zase mohou sloužit jako výchozí podklad pro komplexní posouzení životní situace klienta, které zohledňuje různé kontextuální aspekty jeho situace. Mohou být též východiskem pro hodnocení rovnosti odlišných členů či skupin ve společnosti a tvořit kriteriální základ pro deklaraci jejich práv. ${ }^{29}$ Pro účely tohoto textu bylo zvoleno právě pojetí objektivního well-beingu, jelikož se jeví jako vhodnějši pro demonstraci všestrannosti dopadů rizik pandemie na kvalitu života. Přesto je nutno podotknout, že i hodnocení dopadů v kontextu subjektivního well-beingu by bylo jistě neméně prínosné, ale patrně by vyžadovalo dlouhodobější a hlubší bádání na základě retrospektivních rozhovorů hodnotících delší časový interval. V současné době by závěry takové

21 Sylvie SULKOVÁ a kol., Hemodialýza, Praha: Maxdorf, 2000, s. 513.

22 Srov. Bohuslav HODAŇ, Tomáš DOHNAL, Rekreologie, Olomouc: Hanex, 2005.

23 World Health Organization, Measuring quality of life, Geneva: World Health Organization, 1997, s. 1.

24 Tamtéž, s. 4.

25 Srov. Ivan WILMOT, Bradley S. MARINO, Quality of Life and Psychosocial Care in Pediatric Heart Failure, in: Heart Failure in the Child and Young Adult, ed. John JEFFERIES, Anthony CHANG, Joseph ROSSANO, Robert SHADDY, Jeffrey TOWBIN, London: Academic press, 2018.

26 Eva DRAGOMIRECKÁ, Jitka BARTOŇOVÁ, WHOQOL-BREF, WHOQOL-100: Př́ručka pro uživatele české verze dotazníků kvality života Světové zdravotnické organizace, Praha: Psychiatrické centrum, 2006.

27 Luca D’ACCI, Measuring Well-Being and Progress, Social Indicators Research 1/2011, s. 49.

28 Srov. Karel ŘEZÁČ, Koncepce capability approach a její implikace posilující humanitu (nejen) sociální práce, Caritas et Veritas 2/2019, s. 41-44.

29 Tamtéž, s. 47. 
studie byly patrně velmi hypotetické a nepřesné.

Univerzální a multidisciplinární pohled na kvalitu života s potenciálem propojení se sociální prací byl tedy formulován $\mathrm{v}$ rámci koncepce capability approach. Tato koncepce usiluje o vyjasnění časté záměny hodnotových cílů za prostředky $\mathrm{k}$ jejich dosažení. Produkce a prosperita (potažmo i zdraví) jsou obecně vnímány jako hodnotné, ačkoliv zpravidla neplní explicitně roli hodnoty, nýbrž pouze cesty k jejímu dosažení. Samotná hodnota se skrývá v konkrétních stavech bytí a činnostech (fungování), které jsou v rámci této koncepce označovány jako potenciality (v originále capabilities). ${ }^{30}$ Potenciality lze formulovat v konkrétní podobě deseti základních oblastí, jejichž dostupnost podmiňuje hodnotu kvality života: (1) život; (2) tělesné zdraví; (3) tělesná integrita; (4) smysl, představivost a myšlení; (5) emoce; (6) praktické uvažování; (7) vztahy - (a) sociální vazby, (b) sociální podmínky; (8) jiné druhy; (9) hra; (10) kontrola nad svým prostředím - (a) politická, (b) materiální. ${ }^{31}$

Mezi potencialitami, respektive fungováním, přitom není žádná hierarchie, jelikož každý vycházíme z odlišných hodnot a zkušeností. ${ }^{32} \mathrm{Z}$ tohoto důvodu se koncepce potencialit jeví jako vhodný normativní rámec pro účely tohoto textu a reflexi dopadů koronavirové krize i mimo prioritizované oblasti zdraví a materiální kontroly. Zkoumání vycházející z potencialit je charakterizováno citlivostí na osobní, kulturní, sociální a politické vlivy, čímž přináši řadu nových poznatků, které umožňují sledovat nejenom momentální situaci, ale dokážou odhalit i budoucí trendy. Přístup vycházející $\mathrm{z}$ potencialit zdůrazňuje potřebu sledovat při řešení nepříznivých životních situací klientů sociální práce také jejich zdroje, možnosti a potenciál. ${ }^{33}$ Široký a pestrý náhled na kvalitu života, který tato koncepce poskytuje, navíc koresponduje s komplexní optikou sociální práce.

\section{Dopady koronavirové krize v kontextu potencialit}

První potencialita život konkrétně představuje příležitost člověka žít život v běžné délce. Přímo rizikem potenciálního dopadu pandemie koronaviru se zabývali autoři studie publikované v září 2020 v odborném multidisciplinárním časopise PLOS ONE. Na základě modelu vytvořeného ve studii, který simuluje několik pravděpodobných scénářů vývoje epidemie, autoři konstatovali, že i pouhá $2 \%$ výskytu nemoci covid-19 v populaci státu mohou způsobit pokles průměrné délky života $\mathrm{v}$ zemích, ve kterých se tento indikátor kvality života pohybuje vysoko okolo průměru 80 let. Zmíněný model bere v úvahu srovnání celkového počtu prokazatelně infikovaných osob s počtem evidovaných úmrtí na nemoc covid-19 a souhrnným počtem úmrtí z jiných příčin. Reflektuje tedy obecné snížení délky života u celkové populace. ${ }^{34}$ Jak již bylo zmíněno výše, dopad na tělesné zdraví je v kontextu koronavirové krize vcelku evidentním a velmi často skloňovaným dopadem, na který již upozornila sama Světová zdravotnická organizace prohlášením, že u některých pacientů se vyskytují zdravotní komplikace, které mohou mít trvalé následky na zdraví člověka. ${ }^{35}$ Mimo explicitní vliv pandemie na zdraví však lze předpokládat také dopady implicitní.

30 Srov. Amartya SEN, Development as Capability Expansion, in: Readings in Human Development, ed. Sakiko FUKUDA-PARR, A. K. Shiva KUMAR, New Delhi and New York: Oxford University Press, 2003.

31 Martha NUSSBAUM, Creating Capabilties: The Human Development Approach, Cambridge, MA: Harvard University Press, 2011, s. 33-34.

32 SEN, Development..., s. 43.

33 ○ Jitka NAVRÁTILOVÁ, Capability př́stup jako př́íklad kriticky reflektující praxe sociálních pracovníků (on-line), Sociální práce / Sociálna práca, dostupné na: https://socialniprace.cz/capability-pristup-jako-priklad-kriticky-reflektujici-praxe-socialnichpracovniku/, aktualizace dne 11. 7. 2018, citováno dne 29. 12. 2020.

34 Srov. Guillaume MAROIS, Raya MUTTARAK, Sergei SCHERBOV, Assessing the potential impact of COVID-19 on life expectancy, PLOS ONE 9/2020, s. 23.

35 (c) World Health Organization, What we know about Long-term effects of COVID-19 (on-line), dostupné na: https://www.who.int/docs/ 
Na odhad konečného dopadu na zdraví všech, tedy i těch, kterým se nákaza nemocí covid-19 vyhnula, je v současné době př́liš brzy a relevantní studie podobného typu se pravděpodobně teprve v budoucnu objeví. Již nyní však lze například ze zpráv nadace The Commonwealth Fund, podporující kvalitu a efektivitu zdravotního systému, pozorovat takové změny v ambulantní zdravotní péči, na jejichž základě lze takové dopady předpokládat. V dubnu 2020 byl na základě analýzy dat zjištěn pokles ambulantních lékařských prohlídek o téměř $60 \%$, a přestože v dalším průběhu pandemie již toto číslo nebylo tak dramatické, stále je počet standardních prohlídek a vyšetř̌ení u řady lékařských specialistů znatelně nižší. ${ }^{36}$ Ač tělesná integrita na první pohled spíše než s koronavirovou krizí souvisí zejména s překonáváním bariér, kterým jsou vystaveni lidé s fyzickým hendikepem, v koncepci potencialit je její význam obecnější a zahrnuje možnost svobodné mobility v širším slova smyslu, tedy i př́ležitosti volného cestování. Právě omezení cestování se s pandemií explicitně spojuje a představuje jeden z nejznatelnějších zásahů do lidské svobody v zájmu ochrany veřejného zdraví. Restrikce související s omezením cestování a svobodného pohybu osob $\mathrm{v}$ době karantény přitom měly dopad jak na mezinárodní obchod ${ }^{37}$, tak také na sociální a psychické aspekty kvality života spojené např́ílad s prožíváním distresu a se zvýšeným rizikem výskytu psychických onemocnění. ${ }^{38}$ Podobně lze nahližet na potencialitu smysl, představivost a myšlení, jejíz součástí je i př́ležitost vzdělávat se či praktikovat svou víru. Předpovědi některých studií poukazují na relevantní obavy z dlouhodobých dopadů absence prezenční výuky na studijní výsledky žáků a studentů a výrazné zvýšení variability dovedností a vědomostí mezi jednotlivými žáky. ${ }^{39}$ Restrikce týkající se náboženství v důsledku koronavirové krize dosáhly takových rozměrů, že např́klad Mezinárodní aliance pro náboženskou svobodu sepsala společné prohlášení, v němž upozorňuje na časté porušování náboženských svobod v důsledku př́liš restriktivních opatření omezujících svobodu vyznání a projevu vlastní víry například v podobě zákazu konání bohoslužeb, praktikování víry a realizaci náboženské výuky. ${ }^{40} \mathrm{Za}$ intenzivně zasaženou potencialitu koronavirovou krizí lze také považovat oblast emocí. Vedle již zmíněného strachu, který je možno dokonce označit za symbol doby koronaviru, ${ }^{41}$ je na místě zmínit např́iklad dopady omezení pietních aktivit. Stát se pozůstalým v koronavirové době představuje výzvu v každé fázi pohřebního procesu, od plánování až po pohřební rituál a zajištění náhrobního kamene. Vedle toho lze očekávat dlouhodobě negativní dopady vyplývající z nedostatečné podpory zvládání traumat spojených s náhlým odchodem nejbližších. ${ }^{42}$ Potencialita praktického uvažování znamená možnost realizace individuálních životních plánů prostřednictvím zajištěné svobody. Omezení svobody a přizpůsobení vlastních plánů prakticky prochází např́íc všemi potencialitami, přesto však lze nalézt interpretaci této potenciality, která by mohla být koronavirovou krizí

default-source/coronaviruse/risk-comms-updates/update-36-long-term-symptoms.pdf, aktualizace dne 9. 9. 2020, citováno dne 29. 12. 2020.

36 Srov. () Ateev Mehrotra a kol., The Impact of COVID-19 on Outpatient Visits in 2020: Visits Remained Stable, Despite a Late Surge in Cases (on-line), dostupné na https://doi.org/10.26099/bvhf-e411, aktualizace dne 22. 2. 2021, citováno dne 29. 3. 2021.

37 Srov. () Bengt SÖDERLUND, The impact of travel restrictions on trade during the COVID-19 pandemic (on-line), dostupné na: https:// voxeu.org/article/impact-travel-restrictions-trade-during-covid-19, aktualizace dne 4. 11. 2020, citováno dne 29. 12. 2020.

38 Srov. Isaac Yen-Hao CHU, Prima ALAM, Heidi J. LARSON, Leesa LIN, Social consequences of mass quarantine during epidemics: a systematic review with implications for the COVID-19 response, Journal of Travel Medicine 7/2020, s. 192.

39 Megan KUHFELD, James SOLAND, Beth TARASAWA a kol., Projecting the Potential Impact of COVID-19 School Closures on Academic Achievement, Educational Researcher 8/2020, s. 562.

40 Srov. ( ) International Religious Freedom Alliance, COVID-19 and Religious Minorities Pandemic Statement (on-line), dostupné na: https://www.state.gov/covid-19-and-religious-minorities-pandemic-statement/, aktualizace dne 20. 8. 2020, citováno dne 29. 12.2020.

41 Srov. Behavio Labs, s.r.o., Strach..

42 (c) Alexander BURRELL, Lucy E. SELMAN, How do Funeral Practices Impact Bereaved Relatives' Mental Health, Grief and Bereavement? A Mixed Methods Review with Implications for COVID-19 (on-line), dostupné na: https://journals.sagepub.com/doi/ pdf/10.1177/0030222820941296, s. 35-36, citováno dne 29. 12. 2020. 
nedotčena. Praktické uvažování je totiž dle některých autorů specifickou potencialitou zasluhující zvláštní pozornost, jelikož je aktivačním faktorem života dle vlastní hodnotové determinace. ${ }^{43} \mathrm{Na}$ druhou stranu můžeme v kontextu dané potenciality uvažovat také tak, že restrikce dopadající na př́stupnost ostatních potencialit de facto způsobují omezení i v rovině praktického uvažování, jelikož realizace svobodných voleb nedosahuje tak rozsáhlé nabídky potenciálních variant, čímž tyto volby degraduje. Potencialita vztahů zahrnuje dvě roviny. Jednak vztahy ve smyslu možnosti účastnit se sociálních interakcí a současně vztahy jako možnost přijímat uznání ze strany druhých. Sociální vztahy jsou bez diskuze $\mathrm{v}$ důsledku karantény rovněž výrazně nepř́íznivě ovlivněny koronavirovou krizí v obou těchto rovinách. Podle rozsáhlé globální studie sociálních dopadů vedla karanténa k obrovským poklesům vnímání kvality života $\mathrm{v}$ oblasti sociálních aktivit $\mathrm{v}$ rámci rodiny (pokles o $58 \%$ ) i přátelských a sousedských vztahů (pokles o 44,9\%). ${ }^{44}$ Sociální distanc přitom pochopitelně přináši řadu rizik. Jeho nebezpečí spočívá v rostoucím riziku sociálního vyloučení, rostoucím odosobnění, individualismu a ztráty pocitu příslušnosti ke společenství. Dále může být $\mathrm{v}$ důsledku narušení sociálních vazeb nepř́íznivě ovlivněno učení a vývoj. Omezování socializace znamená omezování jedné z nejzákladnějších lidských potřeb. ${ }^{45}$ Přestože pro řadu lidí byla karanténa př́ležitostí k prohloubení vztahů s jinými druhy, respektive zviřaty v podobě domácích mazlíčků a pobyt $\mathrm{v}$ přírodě znamenal mnohdy jediné dostupné zpestřující prostředí trávení času, i v rámci této potenciality můžeme předpokládat eventuální nepř́íznivé dopady. Např́íklad $\mathrm{v}$ př́ípadě lidí, kteří jsou zvyklí na kontakt se zviŕaty mimo svou domácnost (u př́buzných, známých, v zoologických zahradách apod.). Potencialitu hra lze interpretovat jako príležitost smát se, radovat se a užívat si rekreačních aktivit. Dle již zmíněného výzkumu byl pokles zábavy lidí v důsledku pandemie identifikován v rozsahu - 44,9 až - 46,7 \% ${ }^{46}$ Lidé mají razantně méně př́ležitostí navštěvovat restaurace, kavárny, sportoviště a prakticky všechna místa $\mathrm{k}$ trávení volného času. Poslední potencialita kontrola nad svým okolím zahrnuje dvě roviny. Materiální (ekonomická) rovina $\mathrm{v}$ kontextu koronavirové krize je $\mathrm{v}$ současné době vnímána jako velmi zásadní. Diskutována jsou rizika spojená se ztrátou ekonomické produktivity, propadem většiny průmyslových odvětví a služeb i individuálnější rovina spojená s očekáváním vzrůstající míry nezaměstnanosti a ekonomické krize v obecné rovině. ${ }^{47}$ Politická kontrola byla zase přirozeně oslabena v důsledku zavádění krizového řízení jednotlivých států v podobě zavedení nouzového stavu. ${ }^{48}$

Můžeme tedy říci, že dopady koronavirové krize lze pozorovat napříč prakticky všemi aspekty kvality lidského života $v$ jeho jednotlivých potencialitách. Na základě této skutečnosti lze očekávat, že pandemie nepř́znivě ovlivnila či ovlivní životní situaci většiny lidí ve společnosti a u některých může vést $k$ tomu, že budou za účelem vypořádání se s novou podobou své situace odkázáni na podporu sociální práce. Na druhou stranu lze však identifikovat také pozitivní dopady na kvalitu života, přestože v současné době tvoří takové poznatky spíše marginální nebo opomíjenou část důsledků pandemie, $\mathrm{z}$ hlediska vyváženosti je však na místě tyto př́nosy cíleně zmínit. Často skloňovaným pozitivním dopadem pandemie covid-19 jsou zejména změny životního

43 Srov. Annie AUSTIN, Turning Capabilities into Functionings: Practical Reason as an Activation Factor, Journal of Human Development and Capabilities 1/2018, s. 24-37.

44 Achraf AMMAR, Hamdi CHTOUROU, Omar BOUKHRIS a kol., COVID-19 Home Confinement Negatively Impacts Social Participation and Life Satisfaction: A Worldwide Multicenter Study, International Journal of Environmental Research and Public Health $1 / 2020$, s. 13-14.

45 Kevin SIKALI, The dangers of social distancing: How COVID-19 can reshape our social experience, Journal of Community Psychology 8/2020, s. 2435

46 AMMAR a kol., COVID-19..., s. 13.

47 Srov. Amory MARTIN, Maryia MARKHVIDA, Stéphane HALLEGATTE, Brian WALSH, Socio-Economic Impacts of COVID-19 on Household Consumption and Poverty, Economics of Disasters and Climate Change 4/2020, s. 471-472.

48 Usnesení vlády České republiky ze dne 30. záŕí 2020 č. 957. 
prostředí. Ty lze pozorovat nejen na zlepšení kvality ovzduší a klimatu, ale odráží se též na kvalitě vody a života vodní fauny. U některých vodních toků bylo zaznamenáno zlepšení kvality vody až o $50 \%$ a současně byl pozorován návrat mnoha druhů vodních živočichů do svých původních životních teritorií. Uzavření továren, obchodních provozů snížilo úroveň znečištění po celém světě podobně jako omezení dopravy. ${ }^{49}$ Optikou potencialit lze tedy konstatovat nové př́ležitosti $\mathrm{z}$ hlediska potenciality jiné druhy či prímo $z$ draví, nebot je možno předpokládat, že tyto změny povedou v určitém ohledu také $\mathrm{k}$ obecnému zlepšení zdravotního stavu populace. V kontextu potenciality smysl, představivost a myšlení a potažmo potenciality praktického uvažování lze shledat př́nos v digitální inovaci, kterou navzdory již dříve existujícím možnostem spustila až pandemie nemoci covid-19. Tato digitální transformace navíc zajistila větší pozornost samotnému vzdělávání dětí a dříve zřídkakdy využívaným nástrojům umožňující digitální zefektivnění výuky. ${ }^{50} \mathrm{U}$ pracujících se zase do popředí dostává inovativní pohled na práci z domova, která dřive nebyla tolik $\mathrm{v}$ centru pozornosti a nyní se této formě práce dostává i podoby strategického plánu pro její větší proveditelnost. ${ }^{51}$ Možnost práce $\mathrm{z}$ domova (mimo jiné) vedla $\mathrm{v}$ další studii s celkem 1519 respondenty ve věku 18 až 91 let $\mathrm{k}$ tomu, že u $58 \% \mathrm{z}$ dotazovaných bylo zjištěno mimo negativního také pozitivní vnímání dopadů pandemie a restriktivních opatření. Vedle práce $\mathrm{z}$ domova byla akcentována větší možnost odpočinku a paradoxně i intenzivnějšího sociálního kontaktu s blízkými. ${ }^{52}$ Další studie nabízí dokonce př́mo výčet celkem 29 pozitivních dopadů pandemie covid-19, mezi které patří například větší informovanost lidí o významu blízkých sociálních vztahů, globální spojenectví a soudružnost jednotlivých států, předpoklad budoucího upevnění zdravotního systému, nové obchodní př́ležitosti, snížení trestné činnosti apod. ${ }^{53}$ Podobně jako u nepříznivých vlivů lze tedy konstatovat i všestranné příznivé dopady, které mohou být potenciálním zdrojem pro hledání cest $\mathrm{k}$ hodnotnému životu.

\section{Budoucí výzvy pro sociální práci}

Predikce budoucího vývoje mohou být sice někdy nepřesné, jsou však klíčové pro přípravu na změnu situace, která bezesporu po období pandemie koronaviru nastane. Při využití optiky koncepce capability approach se pozornost sociálních pracovníků neobrací pouze ke sledování specifik prostředí klienta, ale koncepce je rovněž velkou inspirací $\mathrm{v}$ tom, že zaměřuje tuto pozornost ke zdrojům a potencialitám, které jsou nezbytnou součástí zlepšování sociálního fungování klientů sociální práce. Analytický pohled prostř̌ednictvím potencialit na posouzení lidského fungování a blahobytu dává sociálním pracovníkům do rukou nástroj, který umožňuje posoudit životní situaci klienta $\mathrm{v}$ situacích, které jsou pro sociální pracovníky spojeny s řadou nejistot. Z hlediska sociální práce přinášejí potenciality velkou řadu podnětů pro oblast posouzení, tedy něčeho, co má pro sociálního pracovníka zcela kruciální význam a má klíčové postavení $\mathrm{v}$ jeho

49 Srov. Ibrahim KHAN, Dawood SHAH, Sayed Suliman SHAH, COVID-19 pandemic and its positive impacts on environment: an updated review, International Journal of Environmental Science and Technology 2/2020, s. 521-530.

50 Srov. Netta IIVARI, Sumita SHARMA, Leena VENTÄ-OLKKONEN, Digital transformation of everyday life - How COVID-19 pandemic transformed the basic education of the young generation and why information management research should care?, International Journal of Information Management 6/2020, s. 5.

51 Lina VYAS, Nantapong BUTAKHIEO, The impact of working from home during COVID-19 on work and life domains: an exploratory study on Hong Kong, Policy Design and Practice 1/2021, s. 59-76.

52 Mandy GIJZEN a kol., The Bittersweet Effects of COVID-19 on Mental Health: Results of an Online Survey among a Sample of the Dutch Population Five Weeks after Relaxation of Lockdown Restrictions, International Journal of Environmental Research and Public Health 23/2020, s. 6-9.

53 Kankanige KARUNATHILAKE, Positive and negative impacts of COVID-19, an analysis with special reference to challenges on the supply chain in South Asian countrie, Journal of Social and Economic Development 1/2020, s. 146. 
činnosti. ${ }^{54} \mathrm{Z}$ hlediska výše uvedeného rozboru dopadů pandemie koronaviru a s ní souvisejících protiepidemických opatření lze předpokládat několik scénářů, které budou charakteristické pro blízkou budoucnost praxe sociální práce.

První očekávaná dimenze souvisí s předpokladem, že výrazné a všudypřítomné dopady koronavirové krize na kvalitu života povedou k obecnému nárůstu klientů sociální práce. Riziko dlouhodobých zdravotních, ekonomických, sociálních a psychologických následků může v samotném důsledku snadno znamenat více lidí v tak nepř́íznivé životní situaci, že za účelem jejího řešení budou vyhledávat pomoc sociálních pracovníků z různých oblastí působnosti sociální práce.

Druhá dimenze dopadů doby koronaviru vytváří větší požadavky na všímavost sociálních pracovníků zejména v rámci komplexního posouzení životní situace klientů sociální práce. ${ }^{55}$ Vzhledem k aspektu komplexnosti krize se budou sociální pracovníci v budoucnu (přinejmenším po určitou dobu) setkávat $\mathrm{s}$ dopady koronaviru $\mathrm{v}$ různých podobách a pestrých souvislostech ovlivňujících kvalitu života a životní situaci klientů sociální práce. Sociální problémy tak získají nový rozměr či př́mo specifický typ problémů, které by mohly dosáhnout takových rozměrů, že se stanou samostatným tématem a specifickou oblastí vyžadující intervenci sociální práce.

$\mathrm{Na}$ základě dvou předchozích uvedených dimenzí lze vyvodit třetí potenciální budoucí scénár̆, respektive výzvu pro sociální práci a společnost jako celek. Pokud se v budoucnu projeví nárůst klientů a krystalizace nové oblasti sociální práce zabývající se dopady koronaviru, bude na místě zabývat se zřízením specializovaných služeb a sociálních programů zaměřujících se na sociální problémy, u kterých je klíčovým specifickým rysem původ obtíží vzniklých v důsledku koronavirové krize a jejích dopado̊.

Paralelně však nové hrozby přinášejí také nové prŕležitosti. Všestrannost pohody člověka umožňuje čerpat zdroje podpory z široké palety možností, proto je nasnadě uvědomovat si a vyhledávat zdroje podporující pozitivní změnu v obtížné životní situaci také mezi pozitivními dopady pandemie. Hypoteticky lze předpokládat, že vědomá křehkost lidstva, se kterou jsme byli v důsledku pandemie konfrontováni, přispěje k vnímané vyšší hodnotě toho, o co jsme (snad) na omezenou dobu byli ochuzeni. O to významnějším zdrojem pak může být např́iklad čas získaný díky digitálně zefektivněném zaměstnání či škole, jenž je využitý k uklidňující procházce uzdravující se prŕrodou.

\section{Závěr}

Koronavirová krize přirozeně přináší hojně diskutované zdravotní a ekonomické následky s rizikem dlouhodobého vlivu. V jejich výraznému akcentu však poněkud zapadají širší souvislosti dopadi̊ pandemie. Perspektiva sociální práce svou charakteristickou komplexností musí klást důraz na to, aby i tyto aspekty dostávaly náležitý prostor ve veřejném diskurzu a současně nebylo zapomínáno na pozitivní efekty, které tyto těžké zkušenosti také přinášejí. Koncepce potencialit prokazuje, že pandemie koronaviru přináší všestranná rizika i nové př́íležitosti pro různé rozměry a indikátory kvality života. Tyto skutečnosti jsou pro sociální pracovníky o to více důležité, že mohou v budoucnu hned $\mathrm{z}$ několika směrů ovlivňovat a do jisté míry transformovat podobu praxe sociální práce jako profese. Je proto na místě vyzvat k ostražitosti, přípravě a plánování reakce na komplexní sociální změny skýtající (ne)příznivý potenciál koronavirové krize. Uplynulý rok 2020 nám umožnil rozšířit své profesní dovednosti o zkušenosti v často zcela nové podobě

54 C NAVRÁTILOVÁ, Capability...

55 Srov. BALÁŽ, Komplexní..., s. 28. 
poskytování sociální pomoci těm, kdo ji potřebují. Využijme tento potenciál k rozvoji a pro plánování strategie, jak se s očekávanými dopady krize vypořádat. Avizované budoucí výzvy pro sociální práci budou vyžadovat upevnění hodnot a cílů sociální práce pro jejich zdárné př̌ekonání a úspěšné napravení koronavirem vyvolané nerovnováhy ve společnosti. Připravme se společně a postupně začněme budovat takovou praxi, která nás nejenže vrátí $k$ tak kýžené původní podobě společenského života, ale rovněž zajistí, aby naše úsilí vypořádat se s očekávanými změnami vedlo k našemu posílení a vlastní kultivaci.

\section{Kontakt}

\section{Mgr. Karel Řezáč, Ph.D.}

Západočeská univerzita v Plzni

Fakulta filozofická

Katedra sociologie

Sedláčkova 15, 30100 Plzeň

rezack@kss.zcu.cz 